\title{
Cytoskeleton changes and
}

\section{impaired motility of monocytes at modelled low gravity}

\section{Journal Article}

\section{Author(s):}

Meloni, M.A.; Galleri, G.; Pippia, P.; Cogoli-Greuter, M.

Publication date:

2006-12

Permanent link:

https://doi.org/10.3929/ethz-b-000035481

Rights / license:

In Copyright - Non-Commercial Use Permitted

Originally published in:

Protoplasma 229(2-4), https://doi.org/10.1007/s00709-006-0210-2 


\title{
Cytoskeleton changes and impaired motility of monocytes at modelled low gravity
}

\author{
M. A. Meloni ${ }^{1}$, G. Galleri ${ }^{1}$, P. Pippia ${ }^{1}$, and M. Cogoli-Greuter ${ }^{2, *}$ \\ ${ }^{1}$ Dipartimento di Scienze Fisiologiche, Biochimiche e Cellulari, Universita di Sassari, Sassari \\ ${ }^{2}$ Space Biology Group, Swiss Federal Institute of Technology, Zürich
}

Received September 4, 2005; accepted November 2, 2005; published online December 16, 2006

(C) Springer-Verlag 2006

Summary. Investigations performed in space have shown that gravity changes affect important cellular mechanisms like proliferation, differentiation, genetic expression, cytoskeletal architecture, and motility in lymphocytes, monocytes, and other mammalian cells. In particular, a dramatic depression of the mitogenic in vitro activation of human peripheral blood lymphocytes was observed at low gravity. The hypothesis of the present work is that a reduced interaction between $\mathrm{T}$ lymphocytes and monocytes, essential for the second signalling pathway, might be one of the reasons for the observed depression of the in vitro activation of human lymphocytes. Cell motility and with it a continuous rearrangement of the cytoskeletal network within the cell is essential for cell-tocell contacts. Whereas nonactivated lymphocytes in suspension are highly motile at low gravity, no data are available so far on the motility of adherent monocytes. It thus can be argued that impaired monocyte locomotion and cytoskeletal changes could be responsible for a reduced interaction of monocytes with $\mathrm{T}$ lymphocytes. In this study, the locomotion ability of J-111 cells, an adherent monocyte cell line, attached to colloidal gold particles on coverslips and exposed to modelled low gravity in the random positioning machine was found to be severely reduced compared with that of controls and the structures of actin, tubulin, and vinculin were affected.

Keywords: Monocyte; Locomotion; Cytoskeleton; Microgravity; Random positioning machine.

\section{Introduction}

Remarkable findings in space and gravitational biology have shown that mammalian cells subjected to modelled lowgravity conditions on ground as well as to spaceflight conditions in dedicated space missions and in several sounding-rocket flights, are showing alterations in their

\footnotetext{
* Correspondence and reprints: Space Biology Group, Swiss Federal Institute of Technology, Technopark, Technoparkstrasse 1, 8005 Zürich, Switzerland.

E-mail: marianne.cogoli@spacebiol.ethz.ch
}

structure and function (Cogoli and Cogoli-Greuter 1997, Lewis 2002).

Cells of the immune system are in particular the most severely affected by the space environment. Especially for $\mathrm{T}$ lymphocytes, it is known that exposure of cells in culture to actual or modelled low gravity is often accompanied by a major inhibitory effect, remarkably reducing their mitogenic activation process (Cogoli et al. 1984) and severely altering growth rate, cytokine production, gene expression, cytoskeletal structures, and motility (for reviews, see Cogoli 1993, 1997; Cogoli and Cogoli-Greuter 1997; Lewis 2002; Cogoli-Greuter 2004). Furthermore, it has been demonstrated that human lymphocytes are forced to apoptosis in modelled low gravity, through a pathway based on calciumdependent 5-LOX activation, mitochondrial membrane disruption, and cytochrome $c$ release, followed by caspase activation and cell death (Maccarrone et al. 2003).

The mechanism of T-cell activation is very complex and is based on three distinct pathways (Crabtree and Clipstone 1994). Interaction between $T$ cells and the antigen-presenting cells is the first step in the signal transduction, whereas in a next step a costimulatory signal is delivered most probably by accessory cells (usually monocytes) via B7/CD28 interaction (Geppert et al. 1990).

Leukocytes are highly motile cells. Their locomotion is crucial not only for recruiting cells into inflammatory sites but also for their migration and for the contact interactions of antigen-bearing accessory cells with lymphocytes in induction of the immune response. The locomotor capacity of lymphocytes varies with their activation status, whereas monocytes have acquired locomotor capacity during differentiation (Wilkinson 1987). Leukocytes undergoing migra- 
tion, activation, and cell-cell interaction develop a polarized morphology (Sanchez-Madrid and del Pozo 1999) with the formation of two functionally and morphologically distinct poles: the leading edge and the uropod. This involves a reorganisation of the cytoskeletal network with a collapse of the vimentin system, which retracts into the uropod (Brown et al. 2001). During locomotion, the cytoskeletal structures are subjected to repeated cycles of reassembly processes.

Cell-cell interaction and aggregate formation are also important means of cell communication and signal delivery in the mitogenic in vitro activation of human $\mathrm{T}$ lymphocytes extensively studied in real and modelled low gravity. Nonactivated peripheral blood lymphocytes in suspension were found to be motile at low gravity. They displayed an autonomous motion in random directions and often changed their morphology from round shaped to a polarized form (Cogoli-Greuter et al. 1998). Lymphocytes activated at low gravity with the mitogen concanavalin A formed aggregates (Cogoli-Greuter et al. 1996), although they contained fewer cells than the comparable aggregates in the $1 \mathbf{g}$ control on ground. Aggregate formation was observed in real time by video microscopy. The mean velocity of single cells outside the aggregates was significantly higher at low gravity compared with the ground control. Changes in cell activation and signal transduction as well as cell movements and aggregate formation may be related to changes in the cytoskeleton. In fact, marked alterations in the structure of the intermediate filaments of vimentin (Cogoli-Greuter et al. 1998) as well as in the microtubule network (Lewis et al. 1998) were observed in Jurkat cells - a T cell line - after exposure to low gravity.

Since suspended T lymphocytes were found to be highly motile at microgravity even in the absence of the mitogen, it can be argued that an impaired motility of human monocytes acting as accessory cells could hinder the delivery of the costimulatory signal to activate the B7/CD28 pathway and thus could be one of the reasons of the loss of T-cell activation at low gravity. This is supported by the findings that a costimulation of CD3-activated cells by CD28 antibodies in modelled low gravity results in a normal T-cell activation (Vadrucci et al. 2006). In this research, we studied the motility of and cytoskeletal changes in human monocytes J-111 subjected to modelled low-gravity conditions, using the random positioning machine.

\section{Material and methods}

\section{Cell line and cell culture}

$\mathrm{J}-111$ is a monocyte/macrophage cell line derived from human acute monocytic leukemia, obtained from the Istituto Zooprofilattico Sperimentale della Lombardia e dell'Emilia Romagna, Brescia, Italy. This cell line was found to have a HeLa profile by DNA fingerprinting, to display a good adhesion capacity and a certain extent of epithelial morphological polymorphism related to different functional and metabolic status of the cell.

Cells cultured from the frozen stocks were utilised at passage level three to eight for all tests. The cells were grown in RPMI 1640 medium (Glutamax; GIBCO) containing 10\% fetal calf serum (GIBCO), $20 \mathrm{mM}$ HEPES, $5 \mathrm{mM}$ sodium bicarbonate, and $50 \mu \mathrm{g}$ of gentamycin per $\mathrm{ml}$ and were subcultured every 3 days using $0.25 \%$ trypsin-EDTA.

Cytoskeletal structures and motility were studied both at $1 \mathbf{g}$ and modelled low-gravity conditions, using the random positioning machine (RPM) (Dutch Space) as earth-based model of spaceflight, keeping samples under continuous rotation at $60 \mathrm{rpm}$. The time-averaged gravitational vector acting on these samples is reduced to about $10^{-2} \mathbf{g}$.

\section{Cytoskeleton staining}

Analysis of the cytoskeletal structures were performed by an indirect immunofluorescence technique.

J-111 cells were seeded onto chamber slides (Lab-Tek products) at $1.5 \times 10^{4}$ cells per $\mathrm{ml}$ and incubated at $37^{\circ} \mathrm{C}$ for $24 \mathrm{~h}$. Chamber slides, completely fluid-filled, were positioned on the RPM at $37^{\circ} \mathrm{C}$ for $1 \mathrm{~h}$ and $24 \mathrm{~h}$, respectively.

Ground $1 \mathrm{~g}$ controls, not subjected to rotation, were placed onto the machine supporting static frame in order to subject them to the same vibrational stress.

Subsequently all samples were fixed in $4 \%$ paraformaldehyde at $4{ }^{\circ} \mathrm{C}$ for $30 \mathrm{~min}$.

After extensive washing and cell permeabilization with Triton X-100 (Sigma) $10 \%$ in phosphate-buffered saline (PBS) for 3 min, fluorescent staining was performed by exposing the slides to a monoclonal antibody against $\beta$-tubulin (diluted $1: 100$ in bovine serum albumin [BSA]-PBS without $\mathrm{Ca}^{++}$and $\mathrm{Mg}^{++}$[PBSO] from Sigma) and to a monoclonal antibody against vinculin (diluted 1:100 in BSA-PBS from Sigma), both at $37^{\circ} \mathrm{C}$ for $1 \mathrm{~h}$ in a moist chamber. After washing in PBSO and PBS, respectively, a second layer of fluorescein isothiocyanate-conjugated goat anti-mouse gamma globulins (diluted 1:150 in BSA-PBSO or BSA$\mathrm{PBS}$, respectively) was applied for $45 \mathrm{~min}$ at room temperature in the dark. For cytochemical labelling for filamentous actin (F-actin), cells were stained with $5 \mu \mathrm{g}$ of fluorescent phalloidin-tetramethylrhodamine isothiocyanate conjugated solution in PBS with $1 \%$ dimethyl sulfoxide at $37^{\circ} \mathrm{C}$ for $15 \mathrm{~min}$.

Nuclei were stained with $100 \mathrm{ng}$ of $4^{\prime}, 6$-diamidino-2-phenylindole hydrochloride per $\mathrm{ml}$ in PBS for $6 \mathrm{~min}$.

Slides were rinsed in PBS and mounted with immune mount (Shandon) and the cytoskeletal components were observed by fluorescence-inverted microscopy.

\section{Microscopic analysis}

Cytoskeletal structures were observed by fluorescence-inverted microscopy (Olympus) using a magnification of $\times 400$ with oil immersion.

Migration tracks were visualised by a bright-field illumination differential interference contrast (Nomarski) microscope.

Video data were collected using an Olympus charge-coupled-device F View II Image camera coupled to the Analysis software to calculate the cell displacement. Tracks were counted for each experiment, from $1 \mathbf{g}$ controls and samples exposed to modelled low gravity.

\section{Locomotion assay}

The locomotion, i.e., the displacement of cells on an artificial substrate, has been successfully quantified in the past by different authors (Burk 1973, DiPasquale 1975). Also a quantitative assay for the motility phenomena in spreading animal cells in culture, which are associated with large surface 
extensions, i.e., lamellipodia and filopodia (microspikes), has been described (Albrecht-Buehler and Lancaster 1976). Freshly suspended cells, plated on top of a gold particle-coated coverslip, produce various surface protrusions and remove the particles within a ring around each cell. The reaction of the spreading cell microspikes upon contact to colloidal gold particles leads to a centripetal transport of particles to the cell body during the very early stages of cell spreading and to a cleaned area around each cell (Albrecht-Buehler and Goldman 1976). This phenomenon can be used to quantify the motile activity of such protrusions under various extracellular conditions. In fact, during their spreading the cells begin to move while cleaning more particles out of their way. The particles around the cells are mostly cleaned out by surface protrusions during the first hour after plating and become partly internalised (phagocytosed) and partly accumulated on the cell surface in big clumps without being phagocytosed (AlbrechtBuehler and Lancaster 1976). Therefore, the movement of such cells reflects a surface movement rather than a cytoplasmic movement (Albrecht-Buehler and Yarnell 1973). In order to distinguish locomotion on plain surfaces from this combination of phagocytosis and cellular displacement, we better indicate this phenomenon as "phagokinetics" and the particle-free tracks conveniently visualised as "phagokinetic tracks".

In approaching the problem of quantifying the motile behaviour of monocytes in modelled low gravity (or the phenomena of the motile actions of surface protrusions) we plated J-111 cells onto chamber slides coated with colloidal gold (Sigma) according to Albrecht-Buehler and Lancaster (1976).

Exposure of the cells to gold particles $\left(1.45 \mathrm{mM} \mathrm{AuCl}{ }_{4} \mathrm{H}\right)$ had no obvious toxic effects as proven by preliminary viability tests (trypan blue dye exclusion test). J-111 cells showed normal growth and spreading on gold-coated coverslips.

\section{Gold coating}

Chamber slides were incubated with BSA $\left(10 \mathrm{mg} / \mathrm{ml}\right.$ of tridistilled $\left.\mathrm{H}_{2} \mathrm{O}\right)$ at room temperature for $10 \mathrm{~min}$, then quickly washed with $100 \%$ ethanol and incubated at $85{ }^{\circ} \mathrm{C}$ for $10 \mathrm{~min}$. Subsequently, $5 \mathrm{ml}$ of the gold suspension was added at $60-80{ }^{\circ} \mathrm{C}$, and after $45 \mathrm{~min}$ of incubation, the chamber slides were washed in normal salt solution $(113 \mathrm{mM} \mathrm{NaCl}, 3 \mathrm{mM} \mathrm{KCl}, 1 \mathrm{mM}$ $\mathrm{MgCl}_{2}, 15 \mathrm{mM}$ Na-phosphate, $\mathrm{pH}$ 7.8, in tridistilled $\mathrm{H}_{2} \mathrm{O}$ ). Chamber slides were filled with $3 \mathrm{ml}$ of culture medium and kept at $37^{\circ} \mathrm{C}$ until needed for the cell inoculation. J-111 cells were plated at $1.5 \times 10^{4}$ cells per $\mathrm{ml}$ and incubated at $37^{\circ} \mathrm{C}$ for $4-5 \mathrm{~h}$ to allow them to adhere.

Cells attached to coated chamber slides were exposed to modelled low gravity on the RPM for $1 \mathrm{~h}$ and $24 \mathrm{~h}$ and then fixed in $4 \%$ paraformaldehyde at $4{ }^{\circ} \mathrm{C}$ for $30 \mathrm{~min}$. A simultaneous $1 \mathrm{~g}$ control was performed as described above.

\section{Statistical analysis}

After grouping displacement ranks, the frequency percentages (percentage of cells showing a displacement in the distinct groups 1-11) and standard deviation have been calculated. Data were analysed by one-way analysis of variance following the rank sum test by the Sigma Stat program. The data from at least 3 independent experiments monitoring 50 cells per experiment are presented. Statistical significance was accepted at the $\mathrm{P} \leq 0.0001$ level.

\section{Results}

\section{Cytoskeletal architecture}

Cytoskeletal structures of $\mathrm{J}-111$ cells at $1 \mathbf{g}$ conditions showed a well organised network, whereas severe alterations in their structure were observed after $1 \mathrm{~h}$ of expo- sure to modelled low gravity in the RPM. Moreover it has been observed that the actin and tubulin network starts to reorganise to a normal structure after $24 \mathrm{~h}$ of modelled low gravity.

\section{Microfilaments: F-actin}

In the $1 \mathbf{g}$ controls, F-actin filaments appeared abundant and well organised into cytosolic bundles and in the elongated and extended filopodia (Fig. 1A, left panels). Conversely, the F-actin network of J-111 cells exposed to modelled low gravity showed a remarkable decrease in the filamentous biopolymer density and the actin stress fibres appeared localised like continuous subplasmatic bundles, both after $1 \mathrm{~h}$ and $24 \mathrm{~h}$ (Fig. 1 A, right panels). In particular, an initial reorganisation of the actin network was observed after $24 \mathrm{~h}$ exposure to modelled low gravity (Fig. 1A, left panels). This reorganisation of actin might represent an adaptative mechanism and might have relevance in the process of cell adaptation to gravitational unloading.

\section{Microtubules: $\beta$-tubulin}

$\beta$-Tubulin showed a perinuclear position with reduction in aborisation, losing the radial disposition, even after $1 \mathrm{~h}$ of modelled low gravity in the RPM (Fig. 1B, right panels), in contrast to $1 \mathbf{g}$ controls, where they appeared radiating from the microtubule-organising centre to the plasma membrane (Fig. 1B, left panels).

\section{Vinculin}

The anchor protein vinculin appeared as focal contacts linking actin filaments to the plasma membrane in the $1 \mathbf{g}$ controls (Fig. 1C, left panels), whereas samples exposed for 1 and $24 \mathrm{~h}$ to modelled low gravity showed vinculin proteins not evenly spread but thickened close to the cell membrane as globular clusters (Fig. 1C, right panels).

\section{Cell motility}

The microscopic analysis revealed migration tracks of monocytes at $1 \mathrm{~g}$ similar to those described in the literature (Horwitz et al. 1999). A normal pattern of cell migration was observed on gold particle-coated chamber slides of ground samples. Areas around cells appeared completely cleaned out of gold particles partly internalised inside the cells or accumulated to the surface of the cells (Fig. 2B). Conversely, very short migration tracks were observed after both 1 and $24 \mathrm{~h}$ of exposure to modelled 


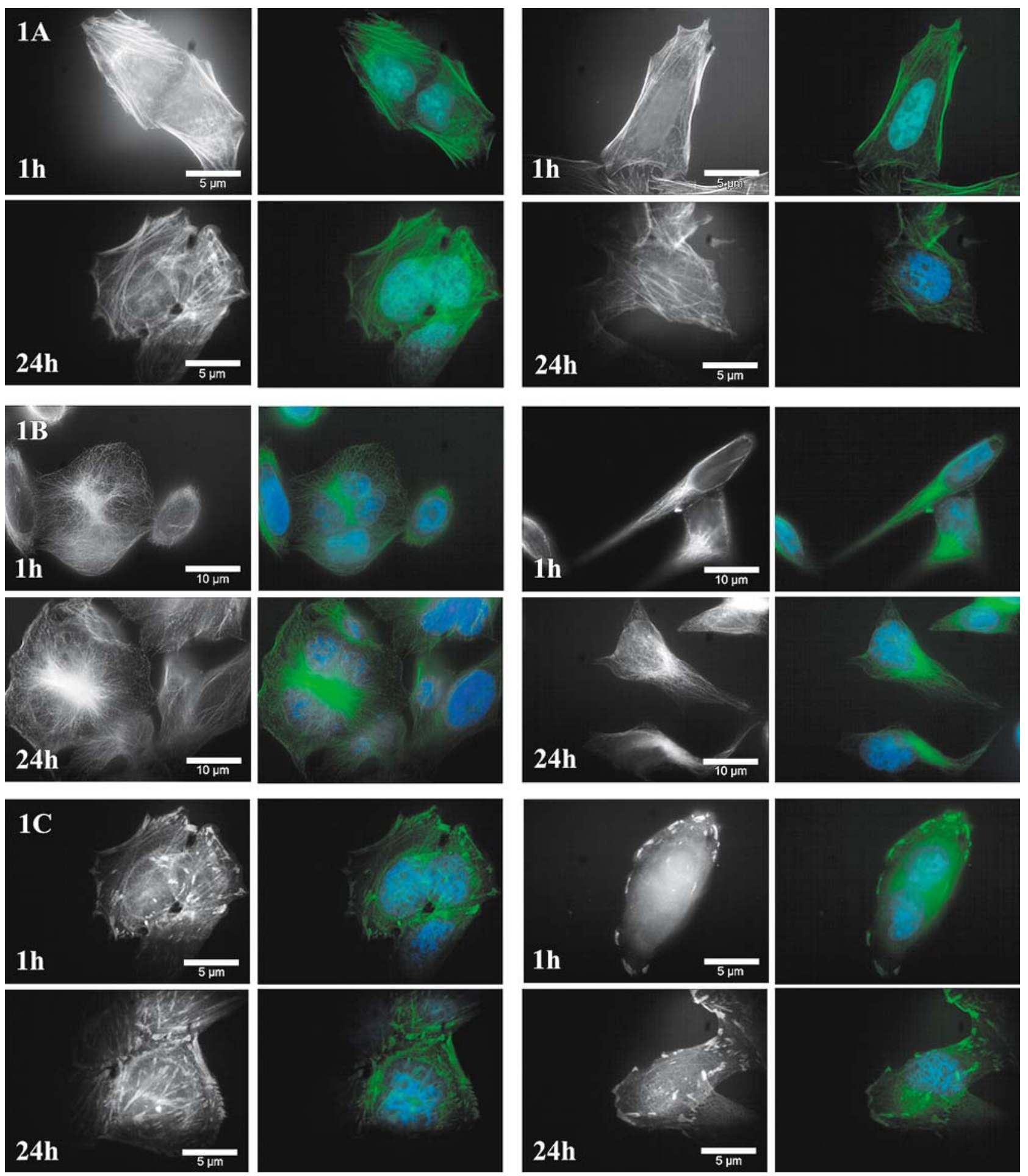

Fig. 1. Immunofluorescence images of F-actin (A), $\beta$-tubulin (B), and vinculin $(\mathbf{C})$ in cultured J-111 cells. Right panels, monochromatic and merge images of samples exposed to RPM for 1 and $24 \mathrm{~h}$. Left panels, $1 \mathbf{g}$ control samples

low gravity (Fig. 2A, C), thus the monocytes were less motile under this condition. In fact, the cell shape appeared more contracted with shorter protrusions reaching the neighbouring cell (Fig. 2A, C), whereas the cells of the $1 \mathbf{g}$ control showed the typical morphology of migrating monocytes (Fig. 2B, D). 

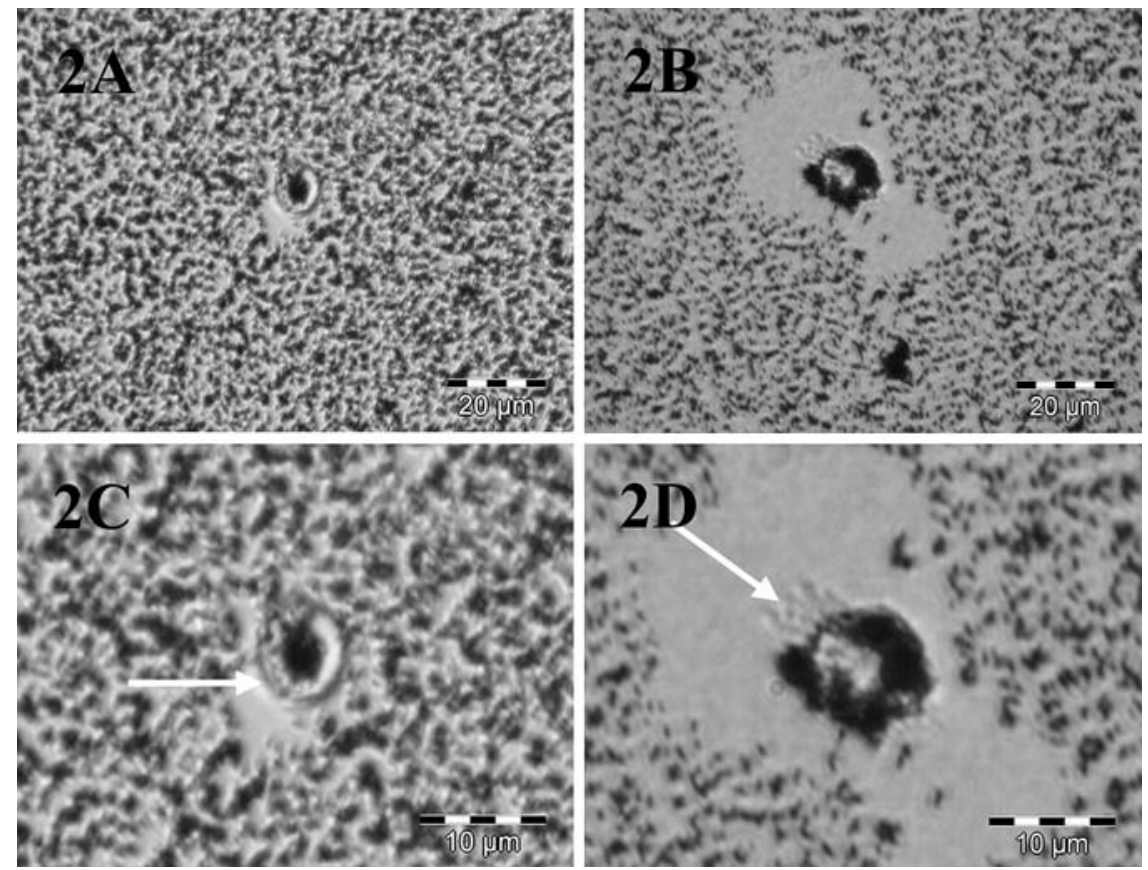

Fig. 2 A-D. Migration tracks on gold particlecoated chamber slides of J-111 cells observed by bright-field illumination differential interference contrast (Nomarski) microscopy. A Very short migration tracks were observed after $24 \mathrm{~h}$ of exposure to modelled low gravity (RPM). This is more evident under higher magnification (C). B and D Control samples showing areas around cell completely cleaned out of gold particles and with typical morphology of migrating cell (arrow)

Cell migration tracks were analysed quantitatively by the Analysis software (Olympus). Data obtained demonstrated a remarkable difference in the locomotion ability of the cells even after $1 \mathrm{~h}$ of modelled low gravity in the RPM when compared to $1 \mathbf{g}$ controls. Cells exposed to
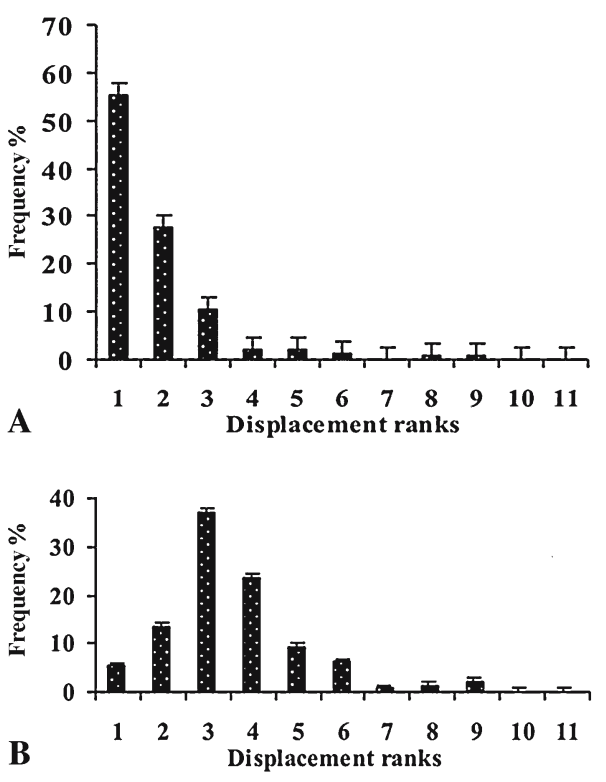

Fig. 3. Displacement frequencies of J-111 cells on gold particle-coated chamber slides after $1 \mathrm{~h}$ of exposure to modelled low gravity (RPM) (A) and to $1 \mathbf{g}$ (B). Displacement rank: 1, 0-4 $\mathrm{m} ; 2,5-9 \mu \mathrm{m} ; 3,10-14 \mu \mathrm{m}$; 4, 15-19 $\mu \mathrm{m} ; 5,20-24 \mu \mathrm{m} ; 6,25-29 \mu \mathrm{m} ; 7,30-34 \mu \mathrm{m} ; 8,35-39 \mu \mathrm{m} ; 9$, $40-44 \mu \mathrm{m} ; 10,45-49 \mu \mathrm{m} ; 11, \geq 50 \mu \mathrm{m}$. The results are the average from at least 3 independent experiments with 50 cells for each experiment modelled low gravity for $1 \mathrm{~h}$ moved on average by $6 \mu \mathrm{m}$ and the most frequent displacement was between 0 and $4 \mu \mathrm{m}$ (Fig. 3A), whereas $1 \mathrm{~g}$ controls showed a displacement of $14.9 \mu \mathrm{m}$ on average and the most frequent displacement was between 10 and $14 \mu \mathrm{m}$ (Fig. 3B). Cells
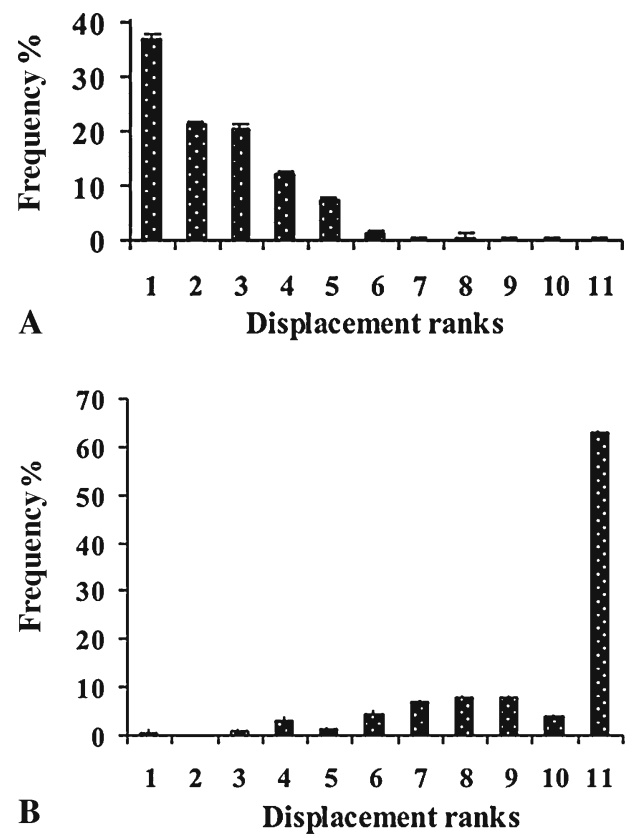

Fig. 4. Displacement frequencies of J-111 cells on gold particle-coated chamber slides ( $\mathrm{Y}$ axis) after $24 \mathrm{~h}$ of exposure to modelled low gravity (RPM) (A) and to $1 \mathbf{g}(\mathbf{B})$. For definitions of displacement ranks see legend of Fig. 3. The results are the average from at least 3 independent experiments with 50 cells for each experiment 
exposed for $24 \mathrm{~h}$ to modelled low gravity showed a total displacement of $8.7 \mu \mathrm{m}$ on average but the most frequent displacement was still between 0 and $4 \mu \mathrm{m}$ (Fig. 4A). Therefore, the total locomotion of monocytes during $24 \mathrm{~h}$ of modelled low gravity appeared to be not much different from that during $1 \mathrm{~h}$. In contrast, the control cells showed a total average displacement of $59.7 \mu \mathrm{m}$ within $24 \mathrm{~h}$ and most of the cells moved $>50 \mu \mathrm{m}$ (Fig. 4B).

\section{Discussion}

The cytoskeleton plays an important role in the cell. It maintains cell shape, provides mechanical support, coordinates and directs cell locomotion as well as cytoplasmic streaming, maintains the organelles and cellular proteins in their proper spatial position with respect to each other, and also plays a key role in signal transduction (Janmey 1998). It is known that a disruption of microfilaments (actin subunits, microtubules, and intermediate filaments) or of the filament association with related proteins has an impact on signal transduction, cell growth, and metabolism (Valitutti et al. 1995).

The cytoskeleton has also been described to be the structure through which the cells sense gravity (Ingber 1999). In fact, different cell types cultured under low-gravity conditions showed cytoskeletal reorganisation. Significant changes were found in the structures of vimentin (CogoliGreuter et al. 1998) and tubulin (Lewis et al. 1998) in Jurkat cells and in the structure of actin in human vascular endothelium cells (Buravkova and Romanov 2001), in osteoblasts (Hughes-Fulford and Lewis 1996) and endothelial cells (HUVEC) (Carlsson et al. 2003). The alterations in the structure of vimentin in Jurkat cells were observed already after an exposure for $30 \mathrm{~s}$ to real low gravity and consisted in the formation of thick bundles compared to the fine network in the $1 \mathbf{g}$ control (Cogoli-Greuter et al. 1998). In the present work, we have observed severe alterations in the structure of F-actin, $\beta$-tubulin, and vinculin in J-111 monocytes exposed for $1 \mathrm{~h}$ to modelled low-gravity conditions compared with $1 \mathbf{g}$ controls. The F-actin network showed a remarkable decrease in the filamentous biopolymer density, and the actin stress fibres appeared localised like continuous subplasmatic bundles. Similar changes in the actin network - especially a disorganisation and reduction of the stress fibres - were also observed in the human vascular endothelial cells, in osteoblasts, and HUVEC cells (Buravkova and Romanov 2001, Hughes-Fulford and Lewis 1996, Carlsson et al. 2003). The changes observed in the microtubule network of J-111 cells were also similar to those observed by Lewis et al. (1998) in Jurkat cells. After
$24 \mathrm{~h}$ exposure to modelled low-gravity conditions, a reorganisation of the actin and tubulin network to a normal structure, as observed at $1 \mathbf{g}$, was taking place. A reorganisation of the microtubule network within $24 \mathrm{~h}$ was also observed in Jurkat cells exposed to low-gravity conditions (Lewis et al. 1998). But it is unclear whether the microtubules reorganise properly despite the fact it appears so. In fact, the functional state of the cells did not return to normal as the cells did not proliferate.

Recent findings highlight the cytoskeleton communication during cell motility and the importance of the intact networks of both cytoskeletal actin filaments and microtubule dynamics in cell movements (Horwitz and Parson 1999). Cell migration begins with an initial protrusion or extension of the plasma membrane at the front (leading edge) of the cell. The protrusions are driven by the polymerisation of the cytoplasmic network of actin filaments at the cell's leading edge and stabilised through the formation of plasma membrane-adhesive complexes, regulated by the combined microtubule activity. Microtubules are also described as regulators of focal adhesion and focal complex turnover that is critical for the continued remodelling and reorganisation of adhesion contacts during cell migration. Key elements that regulate cell migration include the forces generated by actin and myosin contraction, the role of microtubules as a delivery system for focal messages, containing signal molecules that regulate the formation of stress fibres and focal adhesions by activating the Rho/Rac family of signalling molecules (Enomoto 1996).

The acquisition of cell polarity with the reorganisation of the cytoskeletal structures is also a crucial requirement for migration, activation, and apoptosis in leukocytes, i.e., in lymphocytes and monocytes (Fais and Malorni 2003). As we have observed significant changes in the structures of F-actin, $\beta$-tubulin, and vinculin in J-111 monocyte cells exposed to low-gravity conditions, we were not surprised that the locomotion of these cells adhering to colloidal gold particles was disturbed compared with the $1 \mathbf{g}$ controls. In fact, under low-gravity conditions J-111 cells showed a very limited locomotion capability. The cell shape appeared more contracted with shorter protrusions reaching neighbouring cells, whereas cells of the $1 \mathbf{g}$ control showed the typical morphology of migrating monocytes. It is interesting to note that $\mathrm{T}$ lymphocytes in suspension behaved completely different in low gravity (Cogoli-Greuter et al. 1996, 1998). Despite the fact that nonactivated lymphocytes at $1 \mathrm{~g}$ are not motile, we observed a normal motility in lowgravity conditions also in the absence of an activator. Furthermore, lymphocytes in the presence of the mitogen concanavalin A showed a similar motility and did not slow 
down within the 3 days needed for activation, as described for cells at $1 \mathrm{~g}$. The fact that $\mathrm{T}$ lymphocytes are motile in low gravity in the presence of the mitogen may also be the reason that aggregate formation was observed. On the other hand, it can be speculated that no monocytes are in these aggregates and thus no contact between lymphocytes and monocytes - essential for the delivery of the second activation signal - is occurring in low gravity. This could be one of several reasons for the observed depression of the mitogenic lymphocyte activation.

As described for other cell types (Buravkova and Romanov 2001), our results on the motility of J-111 cells clearly revealed that modelled low gravity affects their capacity for locomotion. Buravkova and Romanov (2001) also observed changes in the actin, especially a disorganisation and reduction of stress fibres, i.e., disturbances similar to those observed by us. The importance of an intact and dynamic cytoskeletal network for cell movement has been recently pointed out by Horwitz and Parson (1999). On the basis of our results and those of others, it can thus be speculated that the impaired motility of adherent monocytes in low gravity might be due to the disruption of the cytoskeletal network.

\section{Acknowledgments}

This work was supported by a grant of the Italian Space Agency. We thank M. A. Camboni and A. G. Campus for their invaluable technical assistance.

\section{References}

Albrecht-Buehler G, Goldman RD (1976) Microspike-mediated particle transport towards the cell body during early spreading of 3T3 cells. Exp Cell Res 97: 329-339

Albrecht-Buehler G, Lancaster RM (1976) A quantitative description of the extension and retraction of surface protrusions in spreading 3T3 mouse fibroblasts. J Cell Biol 71: 370-382

Albrecht-Buehler G, Yarnell MM (1973) A quantitation of movement of marker particles in the plasma membrane of 3T3 mouse fibroblasts. Exp Cell Res 78: 59-66

Brown MJ, Hallam JA, Colucci-Guyon E, Shaw S (2001) Rigidity of circulating lymphocytes is primarily conferred by vimentin intermediate filaments. J Immunol 166: 6640-6646

Buravkova LB, Romanov YA (2001) The role of cytoskeleton in cell changes under condition of simulated microgravity. Acta Astronaut 48: 647-650

Burk RR (1973) A factor from a transformed cell line that affects cell migration. Proc Natl Acad Sci USA 70: 369-372

Carlsson SIM, Bertilaccio TS, Ballabio E, Maier JAM (2003) Endothelial stress by gravity unloading: effects on cell growth and cytoskeletal organization. Biochim Biophys Acta 1642: 173-179

Cogoli A (1993) The effect of hypogravity and hypergravity on cells of the immune system. J Leukoc Biol 54: 259-268
Cogoli A (1997) Signal transduction in T lymphocytes in microgravity. ASGSB Bull 10(2): 5-16

Cogoli A, Cogoli-Greuter M (1997) Activation and proliferation of lymphocytes and other mammalian cells in microgravity. Adv Space Biol Med 6: 33-79

Cogoli A, Tschopp A, Fuchs-Bislin P (1984) Cell sensitivity to gravity. Science 225: 228-230

Cogoli-Greuter M (2004) Effect of gravity changes on the cytoskeleton in human lymphocytes. ASGSB Bull 17(2): 27-37

Cogoli-Greuter M, Meloni MA, Sciola L, Spano A, Pippia P, Monaco G, Cogoli A (1996) Movements and interactions of leukocytes in microgravity. J Biotechnol 47: 279-287

Cogoli-Greuter M, Spano A, Sciola L, Pippia P, Cogoli A (1998) Influence of microgravity on mitogen binding, motility and cytoskeleton patterns of $\mathrm{T}$ lymphocytes and Jurkat cells - experiments on sounding rocket. Jpn J Aerospace Environ Med 35: 27-39

Crabtree GR, Clipstone NA (1994) Signal transmission between the plasma membrane and the nucleus of $\mathrm{T}$ lymphocytes. Annu Rev Biochem 63: 1045-1083

DiPasquale A (1975) Locomotory activity of epithelial cells in culture. Exp Cell Res 94: 191-215

Enomoto T (1996) Microtubule disruption induces the formation of actin stress fibers and focal adhesions in cultured cells: possible involvement of the rho signal cascade. Cell Struct Funct 21: 317-326

Fais S, Malorni W (2003) Leukocyte uropod formation and membrane/ cytoskeleton linkage in immune interactions. J Leukoc Biol 73: 556-563

Geppert TD, Davis LS, Gur H, Wacholtz MC, Lipsky PE (1990) Accessory cell signals involved in T-cell activation. Immunol Rev 117: 5-66

Horwitz AR, Parson JT (1999) Cell migration - movin' on. Science 286: $1102-1104$

Hughes-Fulford M, Lewis ML (1996) Effects of microgravity on osteoblast growth activation. Exp Cell Res 224: 103-109

Ingber D (1999) How cells (might) sense microgravity. FASEB J 13 Suppl: S3-S15

Janmey PA (1998) The cytoskeleton and cell signalling: component localization and mechanical coupling. Physiol Rev 78: 763-781

Lewis ML (2002) The cytoskeleton, apoptosis, and gene expression in T lymphocytes and other mammalian cells exposed to altered gravity. Adv Space Biol Med 8: 77-128

Lewis ML, Reynolds JL, Cubano LA, Hatton JP, Lawless BD, Piepmeier EH (1998) Spaceflight alters microtubules and increases apoptosis in human lymphocytes (Jurkat). FASEB J 12: 1007-1018

Maccarrone M, Battista N, Meloni MA, Bari M, Galleri G, Pippia P, Cogoli A, Finazzi-Agrò A (2003) Creating conditions similar to those that occur during exposure of cells to microgravity induces apoptosis in human lymphocytes by 5-lipoxygenase-mediated mitochondrial uncoupling and cytochrome c release. J Leukoc Biol 73: 472-481

Sanchez-Madrid F, del Pozo MA (1999) Leukocyte polarization in cell migration and immune interactions. EMBO J 18: 501-511

Vadrucci S, Henggeler D, Lovis P, Lambers B, Cogoli A (2006) Effects of vector-averaged gravity on the response to different stimulatory signals in T-cells. In: Warmbein B (ed) Proceedings of the 9th European Symposium on Life Sciences Research in Space and 26th Annual International Gravitational Physiology Meeting. Conference proceeding, SP-585. European Space Agency Publications Division, Noordwijk

Valitutti S, Dessing M, Aktories K, Gallati H, Lanzavecchia A (1995) Sustained signalling leading to $\mathrm{T}$ cell activation results from prolonged $\mathrm{T}$ cell receptor occupancy. Role of $\mathrm{T}$ cell actin cytoskeleton. J Exp Med 181: 577-584

Wilkinson PC (1987) Leukocyte locomotion: behavioural mechanisms for accumulation. J Cell Sci Suppl 8: 104-119 
Verleger: Springer-Verlag GmbH, Sachsenplatz 4-6, 1201 Wien, - Herausgeber: Dr. P. Nick, Institut für Biologie, Universität Karlsruhe, Kaiserstraße 2, 76128 Karlsruhe, Bundesrepublik Deutschland. - Redaktion: Sachsenplatz 4-6, 1201 Wien. - Satz und Umbruch: Thomson Press (India) Ltd., Chennai. - Druck: Holzhausen Druck und Medien GmbH, Holzhausenplatz 1, 1140 Wien, - Verlagsort: Wien. - Herstellungsort: Wien. - Printed in Austria 